Sains Malaysiana 49(6)(2020): 1223-1236

http://dx.doi.org/10.17576/jsm-2020-4906-02

\title{
Breeding and Evaluation of Pleurotus giganteus (Berk.) Karunarathna \& K.D. Hyde Hybrids via Intraspecific Mating
}

(Pembiakbakaan dan Penilaian Hibrid Pleurotus giganteus (Berk.) Karunarathna \& K.D. Hyde melalui

Kacukan Intraspesies)

Ha Kwan Yun, Chua Su Boon, TAN YeE Shin* \& ViKineswary Sabaratnam

\section{ABSTRACT}

Pleurotus giganteus, the giant oyster mushroom is gaining popularity as a gourmet mushroom. The cultivation of this mushroom in Malaysia, however, is facing challenges such as malformed pinhead formation and low yield resulting in heavy economic losses for farmers. The aim of this study was to generate new hybrids of $\mathrm{P}$. giganteus with higher yield for commercialisation in Malaysia. The commercial strain of P. giganteus (China) (KLU-M1227) and a wild strain from Malaysia (KLU-M1391) were subjected to intraspecific breeding. A total of 16 hybrids were obtained from 56 combinations. All the parents and hybrids were subjected to linear growth assessment. The hybrids were clustered into slow-growing (growth rate $<0.29 \mathrm{~cm} /$ day) and fast-growing (growth rate in $0.30 \mathrm{~cm} /$ day) types. The parents and three hybrids (IH15, IH17 and IH32) that were the least susceptible to Trichoderma sp. were then cultivated using soil-casing method. This method was able to solve long, coiling stipe formation of $\mathrm{P}$. giganteus. The parent and hybrid strains showed variation in the number of days for pinhead formation and number of fruiting bodies formed. The hybrid with the highest yield (IH32) had a 32\% higher biological efficiency compared to both the parents. Inter simple sequence repeats (ISSR) amplifications were carried out to confirm the generation of the hybrids. Hybrids IHI 7 and IH32 contained the genetic materials inherited from both parents while hybrid IH15 shared high amount of genetic materials from one parent.

Keywords: Biological efficiency; giant oyster mushroom; hybrid; linear mycelial growth

ABSTRAK

Pleurotus giganteus yang lebih dikenali sebagai cendawan tiram gergasi dalam kalangan masyarakat, kini semakin popular sebagai salah satu cendawan gourmet. Walau bagaimanapun, penanaman cendawan ini di Malaysia sedang mengalami pelbagai masalah seperti kecacatan pembentukan putik dan hasil yang rendah lalu menyebabkan kerugian besar kepada petani. Tujuan utama kajian ini adalah untuk menjana hibrid baru P. giganteus dengan hasil yang tinggi untuk dikomersilkan di Malaysia. Pembiakbakaan intraspesies telah dijalankan bagi strain komersil P. giganteus (China) (KLU-M1227) dan strain liar dari Malaysia (KLU-M1391). Sebanyak 16 hibrid berjaya diperoleh daripada 56 gabungan kacukan. Penilaian pertumbuhan linear telah dilakukan bagi induk dan hibrid. Hibrid telah dikelompokkan kepada jenis pertumbuhan perlahan (kadar pertumbuhan $<0.29 \mathrm{~cm} / \mathrm{hari}$ ) dan pertumbuhan pantas (kadar pertumbuhan $\geq 0.30 \mathrm{~cm} /$ hari). Induk dan tiga hibrid (IH15, IH17 dan IH32) yang paling kurang kerentanan terhadap Trichoderma sp. dipilih untuk ditanam menggunakan kaedah salutan tanah. Kaedah ini mampu untuk menyelesaikan masalah pembentukan tangkai buah P. giganteus yang panjang dan berlingkar. Strain induk dan hibrid menunjukkan variasi dalam jumlah bilangan hari bagi pembentukan putik cendawan dan pembentukan badan berbuah. Hibrid dengan hasil tertinggi (IH32) mempunyai kecekapan biologi 32\% lebih tinggi berbanding kedua-dua induk. Teknik amplifikasi Inter Simple Sequence Repeats (ISSR) telah dijalankan untuk menentukan generasi hibrid. Hibrid IH17 dan IH32 didapati mengandungi bahan genetik yang diwarisi daripada kedua-dua induk manakala hibrid IH15 mewarisi bahan genetik yang banyak daripada satu induk.

Kata kunci: Cendawan tiram gergasi; hibrid; kecekapan biologi; pertumbuhan linear misel

\section{INTRODUCTION}

In recent years, commercial mushroom production has increased worldwide contributing to high economic returns to exporting countries such as Poland, China and the United States (Wakchaure 2011). According to the National Agro-Food Policy 2011-2020 (MOA 2019), the Ministry of Agriculture (MOA) of Malaysia regards mushroom as an important food crop which has the potential to contribute to food security and economic 
gains for the country. In Malaysia, Pleurotus species such as $P$. pulmonarius, $P$. floridanus, and $P$. cystidiosus are in demand by the Malaysian consumers. The culinary giant oyster mushroom, $P$. giganteus, though new to Malaysians, is gaining popularity due to its chunky texture and seafood flavour (Nas Agro 2013 personal communication).

$P$. giganteus has high contents of magnesium, potassium, amino acids, iron and calcium which may benefit human health (Phan et al. 2019, 2014). Furthermore, the medicinal properties of $P$. giganteus that have been reported are hepatoprotective (Wong et al. 2012), stimulation of neurite outgrowth (Phan et al. 2012), reduction of isolated skeletal muscular fatigue (Dong et al. 2010; Huang et al. 2005), and inhibition of growth of Candida species (Phan et al. 2013).

$P$. giganteus, previously reported as Lentinus giganteus or Panus giganteus, consists of large fruiting body and is easily recognised (Karunarathna et al. 2011). In Malaysia, it is known as 'cendawan seri pagi' (morning glory mushroom). Wild $P$. giganteus is widely consumed but still not commercialised in Sri Lanka and Thailand (Klomklung et al. 2012). Apart from these countries, occurrence of wild P. giganteus has been reported in Vietnam, Australia (Pegler 1983), China (Bi et al. 1993; Phan et al. 2012) and Oceania (Bi et al. 1993).

$P$. giganteus is one of the popular mushrooms in China, and its biological characteristics, nutritional value and cultivation methods had been studied since 1990 (Dong et al. 2010). Karunarathna et al. (2011) reported that cultivation of $P$. giganteus in Thailand may introduce a high income earning mushroom industry. Klomklung et al. (2012) reported that this mushroom took a long time to fruiting and the yield was low, which may contribute to a higher market price compared to other mushroom species.

In Malaysia, the wild $P$. giganteus has been found growing on the soil in villages in Negeri Sembilan (Batin Long, personal communication, Apr 4, 2014; Batin Seturi, personal communication, Jul 2, 2013). P. giganteus has not been widely commercialised in Malaysia. It was once cultivated at NAS Agro Farm, Sepang (Mr. Nabil, personal communication, Apr 2, 2013). However, the cultivation was discontinued mainly due to severe contamination by fungi. This species was reported to form long coiling stipes in the substrate bag. After harvest, the stipes which remained inside the mushroom bags attracted insects, leading to fungal contamination, infestation with maggots and loss in yield. Sonnenberg et al. (2005) suggested a breeding hybridisation strategy using wild and commercial strains as parents might result in hybrids with beneficial commercial traits. Furthermore, Kothe (2001) emphasised the importance of mating studies and breeding programs to generate improved strains with greater resistance to fungal contamination and higher yield.

Inter simple sequence repeats (ISSR) marker approach took advantage of simple sequence repeats (SSR) or microsatellites that are common throughout the eukaryotic genome by amplifying the region between two similar microsatellites. The method is reproducible and relatively low in cost, time and labour. ISSR methodology is widely applied in several fields of plant research including genomic fingerprinting, genetic diversity, phylogenetic analysis, genome mapping, gene tagging, marker assisted selection, SSR motif frequency determination and evolutionary biology (Reddy et al. 2002). For macrofungi, ISSR markers have been used in the study of genetic diversity (Yin et al. 2014; Zhang et al. 2012), genotyping (Urbanelli et al. 2007) and determining phylogenetic relationships (Sahoo et al. 2014). There is a minimal usage of ISSR markers for identification of hybrids in mushroom related research (Doroteo et al. 2018), while such studies are very common in plant breeding programs (Bianco et al. 2011; Gradzielewska et al. 2012).

In this study, the strains studied were a commercial strain from China collected by NAS Agro Farm and a wild strain as parents. The aims of this study were to evaluate the growth performance and cultivation technique of hybrids produced, and verify the selected hybrids using ISSR markers.

\section{MATERIALS AND METHODS}

FUNGAL STRAINS

The commercial strain Pleurotus giganteus KLU-M1227 was obtained from NAS Agro Farm, Selangor, Malaysia. Meanwhile, the wild strain KLU-M1391 was found caespitose on soil within the vicinity of University of Malaya, Kuala Lumpur. Both strains were identified as $P$. giganteus by Mushroom Research Centre, University of Malaya based on macro-morphological characteristics and molecular analysis. All the fungal strains were maintained as stock cultures in the laboratory.

\section{MATING STUDIES \\ ISOLATION OF SINGLE SPORE CULTURES}

Monokaryons were obtained from a small piece of mushroom lamella by the spore drop method (Petersen $\&$ Bermudes 1992). The lamella was attached to the cover of potato dextrose agar (PDA) (Difco) plate using vaseline. The agar plate was sealed and incubated at room temperature $\left(26 \pm 2{ }^{\circ} \mathrm{C}\right)$ at a slanting angle for 24 h. The lamella was then removed. The agar plate was incubated at room temperature until the basidiospores germinated. The plate was observed under dissecting microscope for germinating single spores. With the help of a modified fine inoculation needle, germinated single 
spores were transferred onto new PDA. The monokaryons on PDA were kept as stock cultures in sterile distilled water and refrigerated at $4{ }^{\circ} \mathrm{C}$ (Castellani 1968).

\section{MATING OF MONOKARYONS FROM DIFFERENT STRAINS}

Fast-growing monokaryon cultures of the two parents were selected for intraspecific mating. Agar plugs of each isolate were placed on PDA plates, $10 \mathrm{~mm}$ apart from each other. The plates were then incubated at room temperature until the mycelia made contact. The mycelium was picked from the contact zone using a needle, mounted on a slide and then checked under compound microscope for clamp connection. The contact zone of the isolates was then cut with a sterile blade and transferred onto a new PDA plate (Bao et al. 2004). Hybrids were kept as stock cultures in sterile distilled water and refrigerated at $4{ }^{\circ} \mathrm{C}$ (Castellani 1968).

\section{LINEAR GROWTH STUDY IN A RACE TUBE}

The substrate consisting of $89 \%$ (w/w) sawdust, $10 \%$ $(\mathrm{w} / \mathrm{w})$ rice bran and $1 \%(\mathrm{w} / \mathrm{w})$ calcium carbonate was prepared in glass race tubes $(160 \mathrm{~mm} \times 25 \mathrm{~mm})$. The moisture content of the substrate was 73 to $74 \%$. The substrate $(58.50 \mathrm{~g})$ was compressed to $100 \mathrm{~mm}$ in length. The tube was stoppered with non-absorbent cotton and then sterilised at $121{ }^{\circ} \mathrm{C}$ for $15 \mathrm{~min}$. A mycelial disc $(1 \mathrm{~cm})$ was taken from a 10 days old culture and then transferred to the substrate surface. The tubes were incubated at $26 \pm 2{ }^{\circ} \mathrm{C}$ in the dark. Visible mycelial extension was recorded at two perpendicular directions every 3 days up to day 15 . The substrate inoculated with the parents was used as control. This experiment was carried out in triplicates for each parent and 16 hybrid cultures generated from mating of monokaryons from different strains.

\section{CULTIVATION OF THE PARENTS AND SELECTED HYBRIDS}

Both the parents and selected hybrids of $P$. giganteus namely $\mathrm{IH} 15$, IH17, and IH32 which were the only fast growing strains with dense mycelium and susceptible to pathogen testing (unpublised data) selected from linear growth study were cultivated on sawdust substrate using the conventional method practiced in mushroom farms with and without soil-casing. Mushroom bags consisting of 73 to $74 \%$ (v/w) water, $89 \%(\mathrm{w} / \mathrm{w})$ sawdust, $10 \%$ $(\mathrm{w} / \mathrm{w})$ rice bran and $1 \%(\mathrm{w} / \mathrm{w})$ calcium carbonate were prepared. The substrate $(300 \mathrm{~g})$ was packed tightly and a central hole was made with the help of a $50 \mathrm{~mL}$ centrifuge tube. The bags were then stoppered with caps and sterilised at $121^{\circ} \mathrm{C}$ for $15 \mathrm{~min}$. After sterilisation, the bags were allowed to cool to room temperature for $24 \mathrm{~h}$. The bags were then inoculated with spawn prepared on wheat grains and were then incubated in the dark at $26 \pm 2$ ${ }^{\circ} \mathrm{C}$. When the bag was $50 \%$ colonised by the mycelium, the wheat grains were removed from the substrate with a sterile spatula in order to reduce contamination by fungi. In the conventional method, 1 week after the mycelia had completely colonised the substrate, the bags were transferred to the mushroom house at Institute of Biological Sciences, Faculty of Science, University of Malaya. The relative humidity around $70 \%$ and a temperature of $29 \pm 6{ }^{\circ} \mathrm{C}$ was maintained in the house. The caps of the mushroom bags were removed for fruiting to occur. For the soil-casing method, garden soil mixed with coconut husks was bought from a nursery at Sungai Buloh, Selangor and sterilised at $121{ }^{\circ} \mathrm{C}$ for $15 \mathrm{~min}$. The soil was slightly moistened with tap water and then $2 \mathrm{~cm}$ height of soil was layered on top of the substrate. The plastic covering of the bag was folded down until it was approximately $3 \mathrm{~cm}$ above the soil layer. Three replicates were set up for each parent and selected hybrids for each cultivation method. The fruiting bodies before maturity (the edge of the pileus was wavy) were harvested by hand. Data such as the time required for spawn completion, duration from stimulation to pinhead emergence, duration from stimulation to harvesting, total weight of fruiting bodies, pileus diameter, stipe length and stipe thickness were recorded (Klomklung et al. 2012). Color descriptions of the fruiting bodies were recorded by referring to Kornerup and Wanscher (1963). The biological efficiency was calculated as given by the formula below:

Biological efficiency $=\frac{\text { Total weight of fresh fruit bodies }}{\text { Dryweight of substrate }} \times 100$

Cultivation method which gave a higher biological efficiency results in all the soil-casing method was then adopted to test the parents and selected hybrids. After harvesting, tissues were transferred from the fruiting bodies of the parents and selected hybrids to PDA using a sterile forceps. Mycelial discs were then transferred to sterilised wheat grain and incubated. Tissue was cut from the fruiting bodies during each generation and cultured in new PDA plates. The processes of spawn run and cultivation were repeated for three generations namely $\mathrm{F}_{1}, \mathrm{~F}_{2}$ and $\mathrm{F}_{3}$. The cultivation data were recorded for the three generations.

\section{ISSR ANALYSIS}

Fruiting bodies of the parents and the hybrids strains (IH15, IH17, and IH32) were collected for analysis. Fruiting bodies were dried using food dehydrator for 24 h. DNA was extracted from dried fruiting body samples of all the parents and hybrids using E.Z.N.A ${ }^{\circledR}$ Forensic DNA Kit (Omega Bio-tek) following the manufacturer's protocol with slight modification. The purity and concentration of isolated DNA were determined using a NanoDrop 2000 spectrophotometer. Twenty arbitrary microsatellite primers (Bioneer Corp, Daejeon, Korea) were pre-selected for PCR amplifications. ISSR amplification was carried out using i-Taq ${ }^{\mathrm{TM}}$ Plus DNA 
Polymerase kit (iNtRON Biotechnology Inc.). Each reaction contained $1 \times \mathrm{i}-\mathrm{Taq}^{\mathrm{TM}}$ Plus PCR buffer, $0.2 \mathrm{mM}$ each dNTP, 0.4 -unit i-Taq ${ }^{\mathrm{TM}}$ Plus DNA Polymerase, 1 $\mu \mathrm{M}$ primer (Table 1), $50 \mathrm{ng}$ sample DNA template and appropriate amount of autoclaved distilled water to make up to final reaction volume of $20 \mu \mathrm{L}$. DNA template was replaced with autoclaved distilled water in the reaction as a negative control. The amplification conditions were as follows: An initial denaturation at $94{ }^{\circ} \mathrm{C}$ for $5 \mathrm{~min}$ followed by 35 cycles of denaturation at $94{ }^{\circ} \mathrm{C}$ for 30 $\mathrm{s}$, annealing at 45 to $52{ }^{\circ} \mathrm{C}$ for $45 \mathrm{~s}$, and extension at 72
${ }^{\circ} \mathrm{C}$ for $90 \mathrm{~s}$, followed by a final extension for $15 \mathrm{~min}$ at $72{ }^{\circ} \mathrm{C}$. PCR products were resolved on $1.8 \%$ agarose gel mixed with RedSafe ${ }^{\mathrm{TM}}$ nucleic acid staining solution. The experiment was carried out in biological duplicates. ISSR fragments were recorded as present (1) or absent (0) of homologous bands. Those fragments with smeared or weak bands were excluded from the analysis. Polymorphic information content (PIC) and marker index (MI) were calculated to assess the performance of each primer (Varshney et al. 2007).

TABLE 1. List of primers used for generation of ISSR data

\begin{tabular}{lcc}
\hline Primer & Sequence $\left(5^{\prime}-3^{\prime}\right)$ & Annealing temperature $\left({ }^{\circ} \mathrm{C}\right)$ \\
\hline P1 & ACACACACACACACACC & 52 \\
P2 & ACACACACACACACACG & 48 \\
P4 & AGAGAGAGAGAGAGAGC & 45 \\
P13 & GGATGCAACACACACACAC & 52 \\
P16 & GTGACACACACACAC & 52 \\
P17 & TGCACACACACACAC & 52 \\
\hline
\end{tabular}

\section{STATISTICAL ANALYSIS}

Analysis of variance (ANOVA) of means of triplicate values was performed using the statistical package for the Social Sciences (SPSS) statistical software version 22 followed by Duncan's multiple range test to determine if there was for significant differences $(p<0.05)$ between treatments.

\section{RESULTS}

\section{MATING STUDIES}

Basidiospores of the parents took 7 to 10 days to germinate and produce the monokaryon cultures. A total of 14 fastgrowing monokaryons of the parent KLU-M1227 were hybridised with 4 monokaryons isolated from the wild parent KLU-M1391. Sixteen hybrids were obtained from 56 combinations with a success rate of $28.6 \%$.

\section{LINEAR GROWTH STUDY}

Both parents and the 16 hybrids took 24 to 49 days to fully colonise the substrate in the race tube. Among the hybrids tested, $37.5 \%$ of them formed primordia in the race tube even before the mycelium had fully colonised the substrate. As shown in Figure 1, the fastest-growing hybrids based on the linear growth rate were IH15 and IH32. Both of the hybrids had a linear growth rate at $0.33 \pm 0.00 \mathrm{~cm} /$ day. Meanwhile, the parents had a lower linear growth rate of $0.18 \pm 0.00 \mathrm{~cm} /$ day (KLU-M1227) and $0.19 \pm 0.00 \mathrm{~cm} /$ day (KLU-M1391), which were $83 \%$ and $73 \%$ lower than the generated hybrids, respectively. The hybrids were grouped as slow-growing (growth rate $<0.29 \mathrm{~cm} /$ day) and fast-growing (growth rate $\geq 0.30 \mathrm{~cm} /$ day) based on the median ( $\mathrm{M}=0.29)$ (Figure 1). All the tested hybrids grew at least $13 \%$ faster than the parents. However, hybrid strains IH15, IH17 and IH32 (growth 
rate $\geq 0.30 \mathrm{~cm} /$ day) were selected for further cultivation evaluated based on susceptibility test (unpublished data). The selected hybrids have better features in mycelial stage namely fast mycelial growth rate and dense mycelium, which are the criteria for relative improvement over parents (Abdulgani et al. 2017; Guadarrama-Mendoza et al. 2014; Sobal et al. 2007).

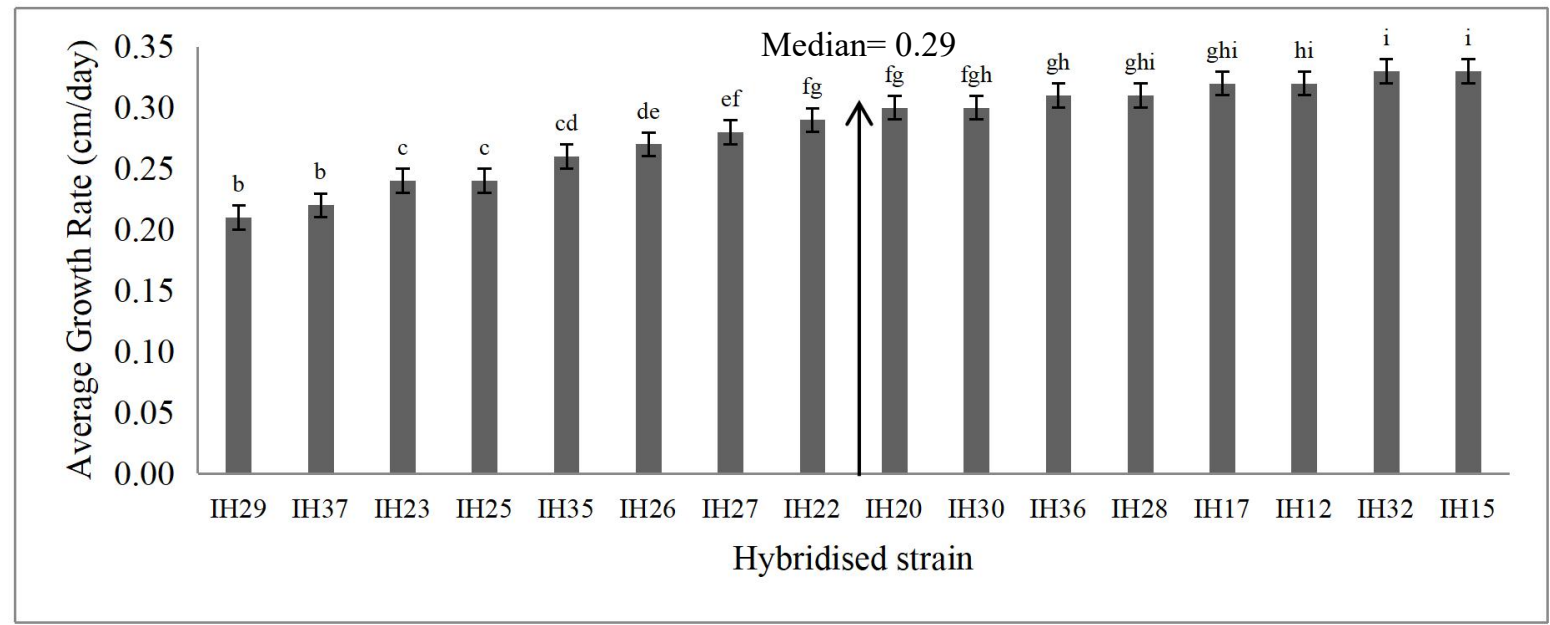

FIGURE 1. Average linear growth rate of hybrids of Pleurotus giganteus at $26 \pm 2{ }^{\circ} \mathrm{C}$ in dark condition [substrate: $89 \%(\mathrm{w} / \mathrm{w})$ sawdust, $10 \%(\mathrm{w} / \mathrm{w})$ rice bran, $1 \%(\mathrm{w} / \mathrm{w})$ calcium carbonate]. Average linear growth rate of the parent KLU-M1227 was $0.18 \pm 0.01 \mathrm{a} \mathrm{cm} /$ day and the parent KLU-M1391 was $0.19 \pm 0.01 \mathrm{a} \mathrm{cm} /$ day. Different letters indicate significant differences by Duncan's multiple range test $(\mathrm{p}<0.05)$

\section{CULTIVATION OF THE PARENTS AND SELECTED HYBRIDS USING CONVENTIONAL CULTIVATION AND SOIL- CULTIVATION METHODS}

Cultivation of the parents and selected hybrids (IH15, IH17, and IH32) was initially carried out using conventional method. Soil-casing method was then adopted to compare the yield as well as the physiological characteristics of the mushrooms of the conventional cultivation method. All the cultivated parents and hybrids were cased with soil 1 week after complete mycelium colonisation of the substrate.
For both cultivation methods, time required for the completion of mycelium colonisation of the substrate by the parents and hybrids of $P$. giganteus took 2 to 4 weeks (Table 2). During the conventional cultivation, the parent KLU-M1391 formed pinheads 2 weeks after spawn run, which was three times faster than the hybrid IH15 whereas in the soil-casing method, the parent KLU-M1227 was the fastest to produce pinheads compared to the wild parent and hybrids. It took 7 days to form pinheads after soil-casing, which was three times faster than the hybrid IH17 (Table 2).

TABLE 2. Fruiting body production of $P$. giganteus using conventional and soil-casing cultivation methods

\begin{tabular}{|c|c|c|c|c|c|c|c|c|c|c|}
\hline \multirow[t]{2}{*}{ Strain } & \multicolumn{2}{|c|}{$\begin{array}{l}\text { Number of days for } \\
\text { spawn completion }\end{array}$} & \multicolumn{2}{|c|}{$\begin{array}{l}\text { Number of days to } \\
\text { show pinhead }\end{array}$} & \multicolumn{2}{|c|}{ No. of fruiting bodies } & \multicolumn{2}{|c|}{$\begin{array}{c}\text { Biological efficiency } \\
(\%)\end{array}$} & \multicolumn{2}{|c|}{ Total no. of flushes } \\
\hline & Conventional & $\begin{array}{l}\text { Soil- } \\
\text { casing }\end{array}$ & Conventional & $\begin{array}{l}\text { Soil- } \\
\text { casing }\end{array}$ & Conventional & $\begin{array}{l}\text { Soil- } \\
\text { casing }\end{array}$ & Conventional & $\begin{array}{l}\text { Soil- } \\
\text { casing }\end{array}$ & Conventional & $\begin{array}{l}\text { Soil- } \\
\text { casing }\end{array}$ \\
\hline \multirow{2}{*}{ KLU-M1227 } & $26.3 \pm$ & $28.0 \pm$ & $28.3 \pm$ & $7.3 \pm$ & $1.6 \pm$ & $3.0 \pm$ & $11.8 \pm$ & $10.1 \pm$ & $1.0 \pm$ & $2.3 \pm$ \\
\hline & $1.6^{\mathrm{c}}$ & $0.0^{\mathrm{c}}$ & $8.3^{\mathrm{abc}}$ & $1.3^{\mathrm{a}}$ & $0.3^{\mathrm{a}}$ & $1.0^{\mathrm{ab}}$ & $1.8^{\mathrm{ab}}$ & $1.2^{\mathrm{ab}}$ & $0.0^{\mathrm{ab}}$ & $0.3^{\mathrm{c}}$ \\
\hline \multirow{2}{*}{ KLU-M1391 } & $24.0 \pm$ & $23.0 \pm$ & $15.6 \pm$ & $12.0 \pm$ & $0.6 \pm$ & $6.0 \pm$ & $5.9 \pm$ & $40.4 \pm$ & $0.3 \pm$ & $2.0 \pm$ \\
\hline & $1.0^{\mathrm{bc}}$ & $0.0^{\mathrm{bc}}$ & $15.6^{\mathrm{abc}}$ & $2.0^{\mathrm{abc}}$ & $0.6^{\mathrm{a}}$ & $0.5^{\mathrm{b}}$ & $5.9^{\mathrm{a}}$ & $1.8^{\mathrm{c}}$ & $0.3^{\mathrm{a}}$ & $0.0^{\mathrm{c}}$ \\
\hline
\end{tabular}




\begin{tabular}{|c|c|c|c|c|c|c|c|c|c|c|}
\hline \multirow{2}{*}{ IH15 } & $16.0 \pm$ & $16.0 \pm$ & $47.3 \pm$ & $19.0 \pm$ & $1.6 \pm$ & $3.6 \pm$ & $28.1 \pm$ & $41.5 \pm$ & $1.0 \pm$ & $2.0 \pm$ \\
\hline & $1.5^{\mathrm{a}}$ & $1.5^{\mathrm{a}}$ & $6.6^{c}$ & $1.7^{\mathrm{abc}}$ & $0.6^{\mathrm{a}}$ & $1.6^{\mathrm{ab}}$ & $2.8^{c}$ & $1.9^{c}$ & $0.0^{\mathrm{ab}}$ & $0.0^{\mathrm{c}}$ \\
\hline \multirow{2}{*}{ IH17 } & $18.3 \pm$ & $16.3 \pm$ & $46.0 \pm$ & $20.3 \pm$ & $2.1 \pm$ & $4.0 \pm$ & $24.3 \pm$ & $37.9 \pm$ & $1.0 \pm$ & $2.0 \pm$ \\
\hline & $0.3^{\mathrm{ab}}$ & $0.3^{\mathrm{a}}$ & $23.1^{\mathrm{bc}}$ & $4.9^{\mathrm{abc}}$ & $1.4^{\mathrm{ab}}$ & $1.0^{\mathrm{ab}}$ & $12.8^{\mathrm{bc}}$ & $2.9^{c}$ & $0.5^{\mathrm{ab}}$ & $0.0^{\mathrm{c}}$ \\
\hline \multirow{2}{*}{ IH32 } & $16.0 \pm$ & $14.0 \pm$ & $26.6 \pm$ & $10.0 \pm$ & $2.8 \pm$ & $11.0 \pm$ & $36.2 \pm$ & $39.8 \pm$ & $1.6 \pm$ & $2.0 \pm$ \\
\hline & $5.0^{\mathrm{a}}$ & $0.0^{\mathrm{a}}$ & $15.2^{\mathrm{abc}}$ & $0.0^{\mathrm{ab}}$ & $0.7^{\mathrm{ab}}$ & $2.4^{\mathrm{c}}$ & $6.5^{\mathrm{c}}$ & $0.6^{\mathrm{c}}$ & $0.3^{\mathrm{bc}}$ & $0.0^{\mathrm{c}}$ \\
\hline
\end{tabular}

Values are mean \pm standard error of three replicates. Values in columns followed by different letters indicate significant differences by Duncan's multiple range test $(p<0.05)$

Long coiling stipes were formed by all the cultivated parents and hybrids in the mushroom bags using conventional cultivation method (Figure 2(C) i-ii). After harvesting, the remaining stipes inside the mushroom bags attracted insects and this eventually led to bag contamination. The parents formed 1 to 2 fruiting bodies whereas the hybrids formed 2 to 3 fruiting bodies on average. In contrast, no long coiling stipe was formed during the fruiting of $P$. giganteus for the soil-casing cultivation method. All of the cultivated parents and hybrids had short stipes in the soil-cased substrate bags (Figure 2(D)). In the soil-casing cultivation, the parents formed 3 to 6 fruiting bodies on average whereas the hybrids formed 4 to 11 fruit bodies.

In Table 2, all the hybrids had at least two times higher biological efficiency compared to the parents in conventional cultivation method whereas in soilcasing method, the parent KLU-M1227 showed the lowest biological efficiency, which was only $10 \%$. However, the parent KLU-M1391 had the second highest biological efficiency compared to all other cultivated parent and hybrids. The biological efficiency of the hybrids was 38 to $42 \%$. The crop of $P$. giganteus harvested in 1 to 2 flushes during conventional cultivation method while 2 flushes on an average were obtained in the soil-casing method. Overall, P. giganteus with soilcasing took shorter time for pinhead formation and formed higher number of fruiting body, higher biological efficiency as well as higher number of flushes compared to the fruiting body production using conventional cultivation method.

Among the parents and hybrids, there was no distinct variation in terms of morphological characteristics such as the colour of fruiting body and pileus margin for both cultivation methods (Figure 2(B), 2(E), 2(F)). For all cultivated strains, the pilei were regular and even, slightly depressed and the pilei surfaces were smooth with scales at the margin. The pilei margins were slightly uplifted in over-matured mushrooms. The pilei colour was yellowish brown (5E5) to dark brown (6F7) in the center, towards the margin yellowish white (4A2) to light brown (6D6). The lamella was pale yellowish white (2A2), subdistant spacing, de-current with narrow breadth. The stipe was 47 to $90 \mathrm{~mm}$ in length, 3 to $8 \mathrm{~mm}$ thick, and the colour varied from greyish brown $(6 \mathrm{~F} 3)$ to orange white (5A2), with solid interior and fibrous texture.

A major problem encountered throughout the period of cultivation (both conventional and soilcasing methods) was the parent KLU-M1227 forming primordia after an average of 18 days but remained as pinhead for a long period without differentiating into pileus. The pinheads were attacked by green mold after 1 month. However, the parent KLU-M1227 was able to differentiate into a relatively small but deformed pileus (Figure 2(A)) when the room temperature was 23 to $32{ }^{\circ} \mathrm{C}$ (night-day) and humidity was 27 to $99 \%$ (daynight). When the room temperature was in the range of 22 to $35{ }^{\circ} \mathrm{C}$ (night-day) and humidity was 18 to 99\% (day-night), the parent KLU-M1227 did not form fruiting bodies. Among the parents and selected hybrids investigated, the parent KLU-M1227 was the only strain with malformation of mushroom pileus (Figure 2(A)).

During the incubation period, though the mushroom house had two humidifiers, there were distinct changes in the external environmental conditions, the temperature of the mushroom house varied at 23 to $38^{\circ} \mathrm{C}$ while the humidity at 14 to $99 \%$ (day-night). These variations resulted in a long period of 'mushroom hibernation' as the primordia were not formed in the conventional method without casing layer. In contrast, substrate cased with the soil layer showed shorter period for pinhead emergence even under such inconsistent circumstances because the soil layer served as a reservoir for water retention.

Since soil-casing cultivation performed better results in all aspects particularly biological efficiency and total number of flushes, this method was carried out for the parents and all the hybrids with 10 replicates each and for three generations. 


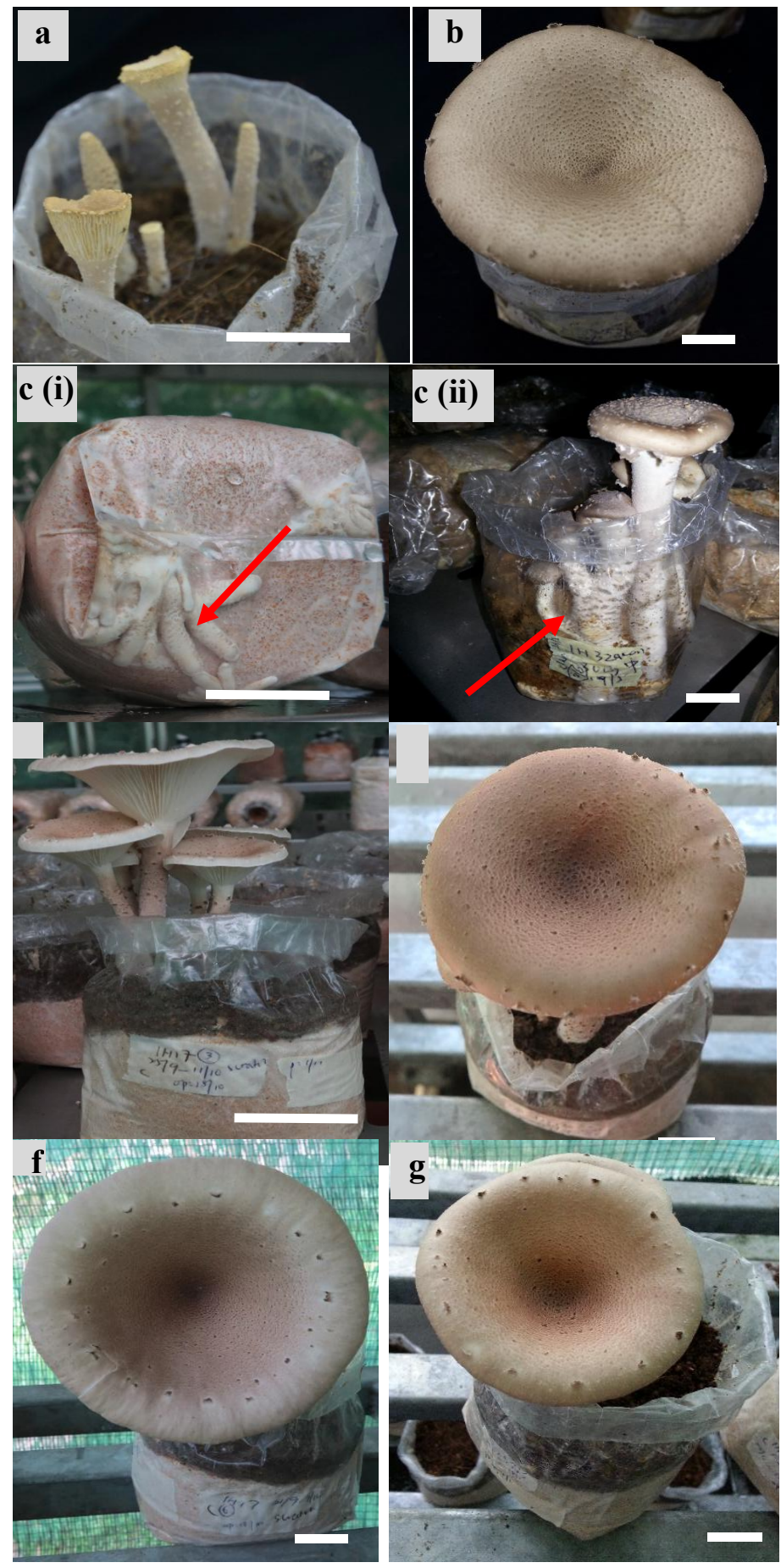

FIGURE 2. Fruiting bodies of the Pleurotus giganteus. a: Parent, KLU-M1227; b: Parent, KLU-M1391; c: Conventional cultivation method; (i) long stipe formed at the bottom of mushroom bag; (ii) long stipe formed by fruiting bodies. d: Absence of long stipe using soil-casing cultivation method; e: Hybrid, IH15; f: Hybrid, IH17; g: Hybrid, IH32. Bars: $20 \mathrm{~mm}$ 
CULTIVATION OF THE PARENTS AND HYBRIDS OF $P$. giganteus USING SOIL-CASING CULTIVATION METHOD

As shown in Table 3, both the parents took 24 to 27 days for spawn completion in the $F_{1}$ generation trials while the hybrids took 2 weeks to fully colonise the substrate in mushroom bags. The parent KLU-M1227, however, was the fastest to produce pinhead among the parents and all the hybrids tested. The pinhead formation of KLU-M1227 was three times faster than that of IH17. The parent KLU-M1227, however, formed the lowest number of fruiting bodies $(1.1 \pm 0.5)$ among the strains. Meanwhile, IH32 formed the highest number of fruiting bodies $(6.8 \pm 1.7)$, which was ten times higher than the primordial formed by KLU-M1227. The parents and hybrids had 1 to 2 flushes on average. Due to the retarded growth, KLU-M1227 formed the smallest pileus (1.0 \pm 0.4 $\mathrm{cm})$ among all the cultivated $P$. giganteus. The pileus size of IH15 (7.2 \pm 0.4$)$ and IH17 (7.2 \pm 0.3$)$ was seven times larger than that of KLU-M1227. The stipe thickness of all the parents and hybrids was 0.5 to $0.9 \mathrm{~cm}$, while the stipe length was 2.8 to $6.4 \mathrm{~cm}$. During the $\mathrm{F}_{1}$ generation trials (temperature was 23 to $35.4{ }^{\circ} \mathrm{C}$ and humidity was 39 to $99 \%$ ), successful fruiting by all hybrids was obtained except $60 \%$ of the parent KLU-M1227 and 10\% of the parent KLU-M1391 did not form fruiting bodies. The biological efficiency of the parent KLU-M1227 was the lowest $(3.73 \%)$ among the parents and all the hybrids evaluated (Figure 3), while the hybrid IH15 had the highest biological efficiency, which was 11 times higher than that of KLU-M1227.

TABLE 3. Comparison of the fruiting body production of the parents and hybrids of $P$. giganteus in three generations using soilcasing method

\begin{tabular}{|c|c|c|c|c|c|c|c|c|}
\hline Strain & Generation & $\begin{array}{l}\text { No. of days for } \\
\text { spawn completion }\end{array}$ & $\begin{array}{l}\text { No. of days for } \\
\text { pinhead formation }\end{array}$ & $\begin{array}{c}\text { No. of fruiting } \\
\text { bodies }\end{array}$ & $\begin{array}{l}\text { Total no. } \\
\text { of flush }\end{array}$ & $\begin{array}{c}\text { Pileus } \\
\text { size }(\mathrm{cm})\end{array}$ & $\begin{array}{c}\text { Stipe } \\
\text { thickness } \\
(\mathrm{cm})\end{array}$ & $\begin{array}{l}\text { Stipe } \\
\text { length } \\
(\mathrm{cm})\end{array}$ \\
\hline \multirow{4}{*}{ KLU-M1227 } & 1 & $23.7 \pm 1.2^{\mathrm{b}}$ & $7.9 \pm 1.3^{\mathrm{a}}$ & $1.1 \pm 0.5^{\mathrm{a}}$ & $1.4 \pm 0.2^{\mathrm{a}}$ & $1.0 \pm 0.4^{\mathrm{a}}$ & $0.5 \pm 0.2^{\mathrm{a}}$ & $2.8 \pm 1.2^{\mathrm{a}}$ \\
\hline & 2 & $19.1 \pm 0.8^{\mathrm{a}}$ & $19.8 \pm 5.9^{\mathrm{a}}$ & $2.0 \pm 0.2^{\mathrm{a}}$ & $1.7 \pm 0.1^{\mathrm{a}}$ & $2.8 \pm 0.1^{\mathrm{b}}$ & $2.3 \pm 0.8^{\mathrm{b}}$ & $7.7 \pm 1.0^{\mathrm{b}}$ \\
\hline & 3 & $25.2 \pm 1.7^{\mathrm{b}}$ & $13.3 \pm 3.7^{\mathrm{a}}$ & $2.0 \pm 0.2^{\mathrm{a}}$ & $1.9 \pm 0.1^{\mathrm{a}}$ & $1.9 \pm 0.3^{\mathrm{ab}}$ & $0.9 \pm 0.1^{\mathrm{ab}}$ & $7.2 \pm 0.3^{\mathrm{b}}$ \\
\hline & Average & $22.6 \pm 1.8^{\mathrm{a}}$ & $13.7 \pm 3.4^{\mathrm{a}}$ & $1.7 \pm 0.3^{\mathrm{a}}$ & $1.6 \pm 0.1^{\mathrm{a}}$ & $1.9 \pm 0.5^{\mathrm{a}}$ & $1.2 \pm 0.5^{\mathrm{a}}$ & $5.9 \pm 1.5^{\mathrm{a}}$ \\
\hline \multirow{4}{*}{ KLU-M1391 } & 1 & $26.8 \pm 0.9^{b}$ & $15.0 \pm 4.1^{\mathrm{a}}$ & $4.0 \pm 0.7^{\mathrm{b}}$ & $1.5 \pm 0.2^{\mathrm{a}}$ & $5.4 \pm 0.8^{\mathrm{a}}$ & $0.8 \pm 0.1^{\mathrm{a}}$ & $4.5 \pm 0.5^{\mathrm{a}}$ \\
\hline & 2 & $17.9 \pm 0.3^{\mathrm{a}}$ & $21.1 \pm 2.7^{\mathrm{ab}}$ & $3.8 \pm 0.5^{\mathrm{b}}$ & $2.1 \pm 0.2^{\mathrm{ab}}$ & $7.6 \pm 0.4^{b}$ & $0.8 \pm 0.0^{\mathrm{a}}$ & $5.9 \pm 0.2^{\mathrm{b}}$ \\
\hline & 3 & $18.5 \pm 1.3^{\mathrm{a}}$ & $32.7 \pm 6.1^{\mathrm{b}}$ & $1.8 \pm 0.1^{\mathrm{a}}$ & $2.7 \pm 0.2^{b}$ & $7.2 \pm 0.3^{\mathrm{b}}$ & $0.9 \pm 0.0^{\mathrm{a}}$ & $6.4 \pm 0.1^{\mathrm{b}}$ \\
\hline & Average & $21.0 \pm 2.8^{\mathrm{a}}$ & $22.9 \pm 5.1^{\mathrm{ab}}$ & $3.2 \pm 0.7^{\mathrm{a}}$ & $2.1 \pm 0.3^{\mathrm{a}}$ & $6.7 \pm 0.6^{\mathrm{b}}$ & $0.8 \pm 0.0^{\mathrm{a}}$ & $5.6 \pm 0.5^{\mathrm{a}}$ \\
\hline \multirow{4}{*}{ IH15 } & 1 & $16.5 \pm 0.4^{\mathrm{a}}$ & $17.2 \pm 1.3^{\mathrm{a}}$ & $5.5 \pm 0.8^{b}$ & $1.9 \pm 0.1^{\mathrm{a}}$ & $7.2 \pm 0.4^{\mathrm{a}}$ & $0.8 \pm 0.0^{\mathrm{a}}$ & $6.4 \pm 0.3^{\mathrm{a}}$ \\
\hline & 2 & $19.7 \pm 0.5^{\mathrm{b}}$ & $20.4 \pm 3.6^{\mathrm{a}}$ & $2.0 \pm 0.4^{\mathrm{a}}$ & $2.0 \pm 0.3^{\mathrm{a}}$ & $6.6 \pm 1.2^{\mathrm{a}}$ & $0.8 \pm 0.1^{\mathrm{a}}$ & $5.8 \pm 0.9^{\mathrm{a}}$ \\
\hline & 3 & $20.3 \pm 0.9^{\mathrm{b}}$ & $45.6 \pm 3.4^{\mathrm{b}}$ & $1.9 \pm 0.2^{\mathrm{a}}$ & $2.0 \pm 0.1^{\mathrm{a}}$ & $8.4 \pm 0.6^{\mathrm{a}}$ & $0.9 \pm 0.0^{\mathrm{a}}$ & $7.7 \pm 0.5^{\mathrm{a}}$ \\
\hline & Average & $18.8 \pm 1.1^{\mathrm{a}}$ & $27.7 \pm 8.9^{\mathrm{ab}}$ & $3.1 \pm 1.1^{\mathrm{a}}$ & $1.9 \pm 0.0^{\mathrm{a}}$ & $7.4 \pm 0.5^{\mathrm{b}}$ & $0.8 \pm 0.0^{\mathrm{a}}$ & $6.6 \pm 0.5^{\mathrm{a}}$ \\
\hline \multirow{4}{*}{ IH17 } & 1 & $16.7 \pm 0.3^{\mathrm{a}}$ & $25.8 \pm 5.4^{\mathrm{a}}$ & $4.4 \pm 0.7^{\mathrm{a}}$ & $1.8 \pm 0.1^{\mathrm{a}}$ & $7.2 \pm 0.3^{\mathrm{a}}$ & $0.9 \pm 0.0^{\mathrm{b}}$ & $6.0 \pm 0.2^{\mathrm{a}}$ \\
\hline & 2 & $17.4 \pm .1 .1^{\mathrm{a}}$ & $59.3 \pm 4.5^{\mathrm{c}}$ & $3.6 \pm 0.4^{\mathrm{a}}$ & $1.7 \pm 0.1^{\mathrm{a}}$ & $10.3 \pm 2.4^{\mathrm{a}}$ & $1.0 \pm 0.0^{\mathrm{b}}$ & $5.4 \pm 0.1^{\mathrm{a}}$ \\
\hline & 3 & $21.6 \pm 1.3^{\mathrm{b}}$ & $45.6 \pm 3.7^{\mathrm{b}}$ & $2.8 \pm 0.2^{\mathrm{a}}$ & $1.8 \pm 0.2^{\mathrm{a}}$ & $6.6 \pm 0.3^{\mathrm{a}}$ & $0.8 \pm 0.0^{\mathrm{a}}$ & $5.9 \pm 0.3^{\mathrm{a}}$ \\
\hline & Average & $18.5 \pm 1.5^{\mathrm{a}}$ & $43.5 \pm 9.7^{\mathrm{b}}$ & $3.6 \pm 0.4^{\mathrm{ab}}$ & $1.7 \pm 0.0^{\mathrm{a}}$ & $8.0 \pm 1.1^{\mathrm{b}}$ & $0.9 \pm 0.0^{\mathrm{a}}$ & $5.8 \pm 0.1^{\mathrm{a}}$ \\
\hline \multirow{4}{*}{ IH32 } & 1 & $14.9 \pm 0.5^{\mathrm{a}}$ & $10.0 \pm 0.4^{\mathrm{a}}$ & $10.3 \pm 1.2^{\mathrm{b}}$ & $2.0 \pm 0.0^{\mathrm{a}}$ & $5.3 \pm 0.3^{\mathrm{a}}$ & $0.7 \pm 0.0^{\mathrm{a}}$ & $5.1 \pm 0.1^{\mathrm{a}}$ \\
\hline & 2 & $17.2 \pm 1.1^{\mathrm{a}}$ & $6.9 \pm 1.1^{\mathrm{a}}$ & $5.4 \pm 0.8^{\mathrm{a}}$ & $2.4 \pm 0.1^{\mathrm{a}}$ & $7.1 \pm 0.5^{\mathrm{b}}$ & $0.9 \pm 0.0^{\mathrm{b}}$ & $6.1 \pm 0.2^{\mathrm{b}}$ \\
\hline & 3 & $23.9 \pm 1.8^{\mathrm{b}}$ & $20.5 \pm 4.4^{\mathrm{b}}$ & $4.7 \pm 1.0^{\mathrm{a}}$ & $2.4 \pm 0.2^{\mathrm{a}}$ & $6.9 \pm 0.2^{\mathrm{b}}$ & $0.7 \pm 0.0^{\mathrm{a}}$ & $6.3 \pm 0.3^{b}$ \\
\hline & Average & $18.6 \pm 2.6^{\mathrm{a}}$ & $12.4 \pm 4.1^{\mathrm{a}}$ & $6.8 \pm 1.7^{\mathrm{b}}$ & $2.2 \pm 0.1^{\mathrm{a}}$ & $6.5 \pm 0.5^{\mathrm{b}}$ & $0.8 \pm 0.0^{\mathrm{a}}$ & $5.8 \pm 0.3^{\mathrm{a}}$ \\
\hline
\end{tabular}


In the second generation evaluation, the parents and all the hybrids showed no considerable difference in the number of days for spawn completion, which was 17 to 19 days. The hybrid IH32 formed pinhead 1 week after soil-casing, which was three times faster than both the parents and the hybrid IH15, but eight times faster than the hybrid IH17. The parent KLU-M1227 and the hybrid IH15 formed 2 fruiting bodies on average during $F_{2}$ generation. IH32 formed the highest number of fruiting bodies (5.4 \pm 0.8$)$ among the parents and all the hybrids. The parents and hybrids had 2 flushes on average. IH17 formed the largest pileus $(10.3 \pm 2.4 \mathrm{~cm})$ among all the cultivated samples, which was around three times of the pileus size of the parent KLU-M1227. Despite the small pileus size, KLU-M1227 had the thickest stipes $(2.3 \pm 0.8$ $\mathrm{cm})$, which was two times thicker than all the others. KLU-M1227 also formed the longest stipe $(7.7 \pm 1.0 \mathrm{~cm})$ among them. During the $\mathrm{F}_{2}$ generation (temperature was 20 to $38{ }^{\circ} \mathrm{C}$ and humidity was 14 to $99 \%$ ), all parents and hybrids fruited except $20 \%$ of the hybrid IH15. Biological efficiency of IH32 was the highest among all the hybrids $(56.79 \%)$, which was four times higher than that of KLU-M1227 (Figure 3).

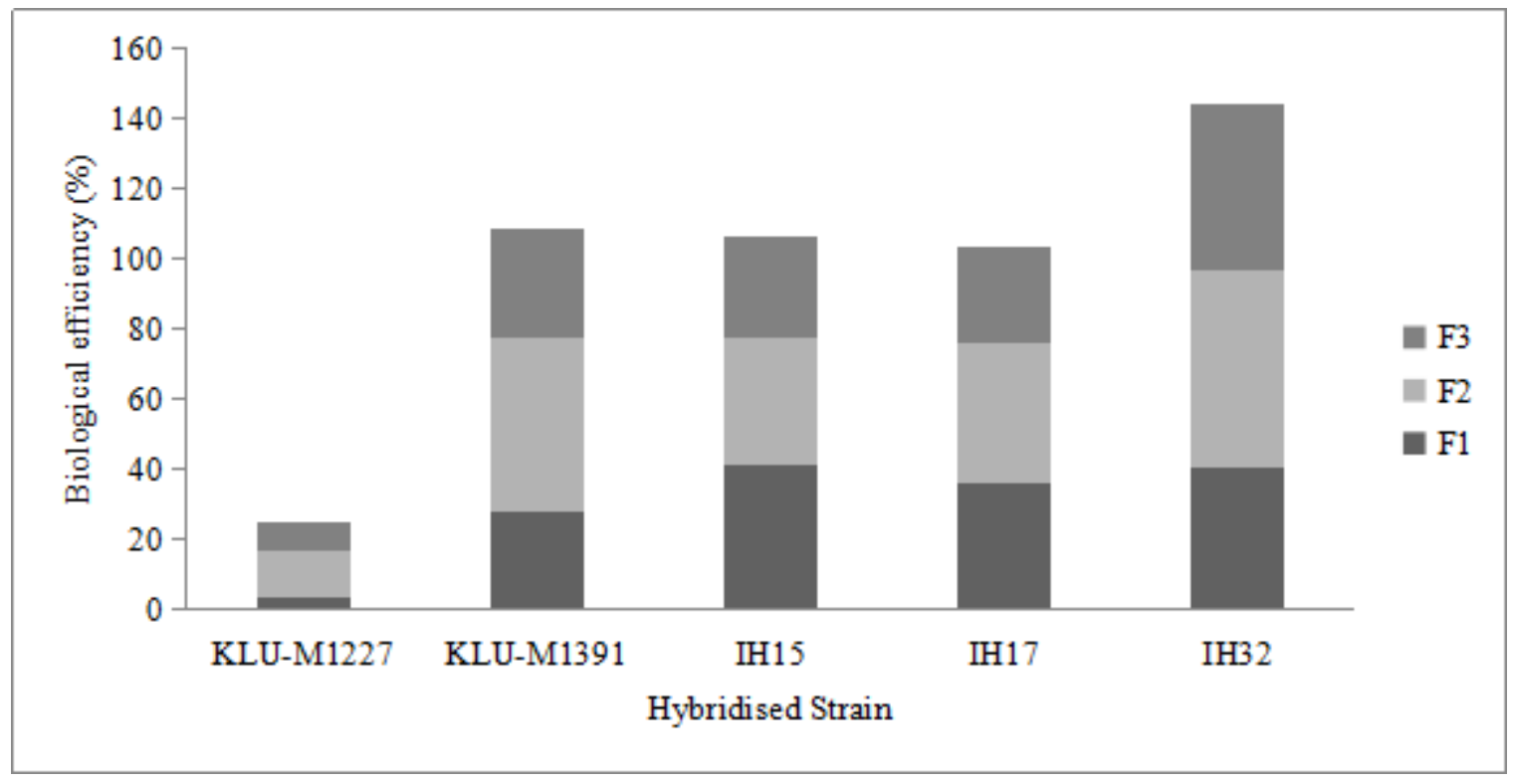

FIGURE 3. Biological efficiency (\%) of the parents and selected hybrids in three generations

The parent KLU-M1391 took the shortest time for spawn completion among all the cultivated $P$. giganteus in the third generation $\left(\mathrm{F}_{3}\right)$ trials. While the parent KLU-M1227 was the slowest to complete spawn run in the mushroom bags. All the hybrids took around 3 weeks for spawn completion. IH32 was the fastest to show pinhead after soil-casing among all the hybrids. It took 20.5 days for pinhead formation, which was $55 \%$ faster than those of IH15 and IH17. Both the parents formed only 2 fruiting bodies in this generation whereas the number of fruiting bodies formed by the hybrids was 2 to 5 . The parents and hybrids had 2 to 3 flushes on average. IH15 formed the largest pileus $(8.4 \pm 0.6 \mathrm{~cm})$ among all the cultivated mushrooms, which was four times larger than that of KLU-M1227. All of the cultivated mushrooms formed similar stipe thickness in this generation, ranging from 0.7 to $0.9 \mathrm{~cm}$. KLU-M1227 and IH15 formed the longest stipes among all the cultivated P. giganteus, which were $7.2 \pm 0.3 \mathrm{~cm}$ and $7.7 \pm 0.5 \mathrm{~cm}$, respectively. During the $\mathrm{F}_{3}$ generation where the temperature was 21.5 to $35.7{ }^{\circ} \mathrm{C}$ and humidity was 14 to $99 \%$, all of the $P$. giganteus fruited. IH32 showed the highest biological efficiency (47.12\%) among all the hybrids, and it was six times higher than that of the parent KLU-M1227 (Figure 3).

Generally, the cultivated parents and all of the hybrids took a longer period for spawn completion compared to the first and second generations except for the parent KLU-M1391. However, they all produced the highest number of flushes in the $\mathrm{F}_{3}$ generation (Table 3). All the parents and hybrids took a shorter period for pinhead formation during the first generation except for IH32.

All the hybrids took an average of 18 days for spawn completion, which was $12 \%$ and $18 \%$ faster than KLU-M1391 and KLU-M1227, respectively (Table 3). 
Variability in time to form pinhead was observed among the strains. Among the hybrids, IH32 was the fastest to fruit, which differed significantly $(p<0.05)$ from the other strains. Pinhead of hybrid IH32 grew at an average of $12.4 \pm 4.1$ days after bag opening while IH15 and IH17 took longer period for pinhead formation compared to both of the parents KLU-M1227 and KLU-M1391. The

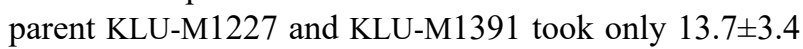
and $22.9 \pm 5.1$ days, respectively, whereas the hybrids IH15 and IH17 had taken $27.7 \pm 8.9$ and $43.5 \pm 9.7$ days, respectively, to form pinhead after bag opening.

Hybrid IH32 produced the highest number of fruiting bodies compared to all other parents and hybrids in all three generations. The average number of fruiting body formed by IH32 (6.8 \pm 1.7$)$ was four times of that of the parent KLU-M1227 (1.7 \pm 0.3$)$ and two times of that of the parent KLU-M1391 (3.2 \pm 0.7$)$. The parents and all the hybrids produced an average of 1 to 2 flushes in the three generations.

The pileus size of the cultivated mushrooms was negatively correlated with the number of fruiting bodies formed whereby the mushroom bags with higher number of fruiting bodies formed smaller pileus. Even though hybrid IH32 had the highest number of fruiting body formed during the cultivation, its pileus size $(6.5 \pm 0.5 \mathrm{~cm})$ was relatively small when compared to the other hybrids. The average pileus size of the cultivated strains was was $6-8 \mathrm{~cm}$, except for parent KLU-M1227 which showed retarded growth with an average of $1.9 \pm 0.5 \mathrm{~cm}$ for pileus size (Table 3). However, KLU-M1227 showed the highest value in stipe thickness $(1.2 \pm 0.5 \mathrm{~cm})$ among all the cultivated strains despite its retarded pileus development.

The hybrid IH32 had the highest biological efficiency among all the cultivated strains throughout all three generations with a mean value of $48.07 \%$. When comparing the fruiting body production among all strains within the three generations, the mushroom yield and biological efficiency during $\mathrm{F}_{2}$ generation were generally higher (Figure 3). The biological efficiency of IH32 during the $\mathrm{F}_{2}$ generation was $335 \%$ higher than the parent KLU-M1227 and 14\% higher than the parent KLU-M1391. Among all the strains, KLU-M1227 showed the least percentage in biological efficiency due to its retarded growth. This parent performed only $3.73 \pm 1.58$ (\%) of biological efficiency during the $F_{1}$ generation. The mean value of the biological efficiency of the hybrids in this study was 34.4 to $48.07 \%$. However, the hybrid with the best yield (IH32) performed $479.66 \%$ and $32.35 \%$ higher in biological efficiency respectively when compared to the parents, KLU-M1227 and KLU-M1391.

\section{MOLECULAR GENETIC ANALYSIS BY ISSR}

Six ISSR primers produced a total of 30 loci with the size ranging from approximately 350 to $1500 \mathrm{bp}$. ISSR P13 produced 7 bands ranging from around 600 to 1500 bp for the parents and hybrids (IH15, IH17, and IH32). PIC values for primers ranged from 0.21 to 0.44 while MI values ranged from 0.61 to 1.48 . Fragment patterns of IH17 and IH32 were shown to possess bands specific to KLU-M1227 and KLU-M1391 (Figure 4). Interestingly, IH15 shared all the bands (22) with KLU-M1391 and only shared 7 bands with KLU-M1227 (Table 4).

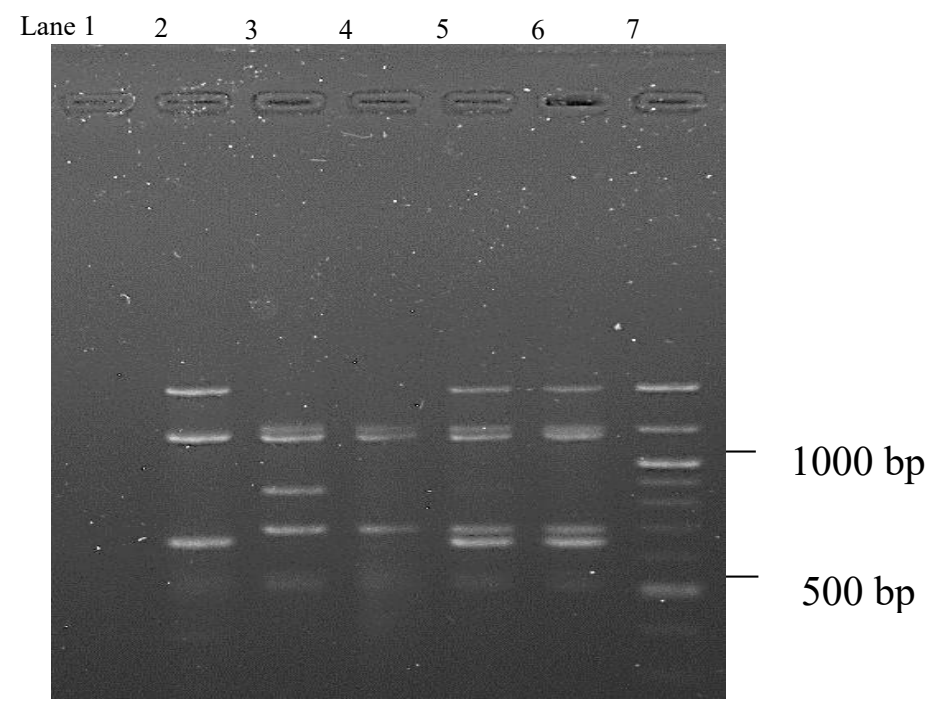

FIGURE 4. Inter simple sequence repeat (ISSR) profile of two parents and hybrids amplified by primer P17. Lane $1=$ Negative control; Lane $2=$ KLU-M1227 (parent); Lane $3=$ KLU-M1391 (parent); Lane 4= Hybrid IH15; Lane 5= Hybrid IH17; Lane 6= Hybrid IH32; Lane 7 = DNA ladder 
TABLE 4. Band shared among all samples

\begin{tabular}{cccc}
\hline Suspected hybrid & $\begin{array}{c}\text { Bands shared with } \\
\text { PG 001 }\end{array}$ & $\begin{array}{c}\text { Bands shared with } \\
\text { PG } 003\end{array}$ & $\begin{array}{c}\text { Bands shared with } \\
\text { both parents }\end{array}$ \\
IH15 & $7(31.8 \%)$ & $22(100 \%)$ & $7(31.8 \%)$ \\
IH17 & $13(48.1 \%)$ & $19(70.4 \%)$ & $6(22.2 \%)$ \\
IH32 & $13(59.1 \%)$ & $16(72.7 \%)$ & $6(27.3 \%)$ \\
\hline
\end{tabular}

\section{DISCUSSION}

This study involved the crossing of basidiospores isolated from commercial and wild strains. This is a common breeding strategy which incorporates quantitatively inherited traits of a wild line into an existing commercial line (Sonnenberg et al. 2005). The mating frequency in this study was $3.6 \%$ higher than the expected mating frequency of tetrapolar basidiomycetes reported by Giraud et al. (2008), which was 25\%. However, other studies showed higher mating frequency in tetrapolar basidiomycetes such as $P$. tuber-regium with 55 to $84 \%$ mating frequency reported by Isikhuemhen et al. (2000), 92\% of mating frequency resulted by intraspecific mating of $P$. ostreatus reported by Kumara and Edirimanna (2009), and $26.3 \%$ of mating compatibility of Hypsizygus marmoreus reported by Lee et al. (2011). In the taxonomic study by Stajić et al. (2005), geographical isolation was said to cause genetic differences in Pleurotus strains. van Peer et al. (2011) also added that geographical distribution caused differences on the multi-allelic nature of mating genes. However, Isikhuemhen et al. (2000) and Lee et al. (2011) showed that tetrapolar mating using intrastock pairings from different geographical origins could achieve high mating compatibility frequency up to $70 \%$ or more. Therefore, there is possibility that the mating frequency in this study can be improved by increasing the number of basidiospores from the parental strains. Larsen et al. (1992) reported that clamp connections have become important as an in vitro indicator for dikaryon formation. Nuclei exchange and migration resulted in clamp cell formation (Brown \& Casselton 2001). Following nuclear division and septation, clamp cell fusion occurs, and this results in a sexually competent dikaryon (Brown \& Casselton 2001; Gharehaghaji et al. 2007).

Linear growth study was carried out to compare the mycelial growth rate between hybrids using a substrate composition commonly used in mushroom farms in Malaysia. According to Kumara and Edirimanna (2009), the genetic differences inherited within different strains may contribute to variation in mycelium colonisation rate of a medium. In this study, the hybrids showed significant $(p<0.05)$ differences in linear growth rate but no variation was observed in the mycelium density on the substrate. This observation was similar to that reported by Mensah and Obodai (2014) that not all the fast-growing strains showed dense mycelium growth. Furthermore, Mensah and Obodai (2014) reported that mycelia growth rate and density is dependent on the media used. Since the linear growth is closely related to the yield of mushroom (Kaur et al. 2014), the linear growth rate in this study was not dependant on the mycelium density and should be taken into consideration when selecting the criteria of the substrate.

The morphological characteristics of the cultivated parents and all the hybrids of $P$. giganteus matched the descriptions by Karunarathna et al. (2011). Anyhow, environmental factors such as temperature, light intensity and carbon dioxide concentration may alter morphological characteristics of fungi (Bao et al. 2004). It was reported that factors such as inadequate light and ventilation, chemical vapours and overheated substrate during spawn run might lead to malformed fruiting bodies (Royse 2003). The abnormal maturation of the parent KLU-M1227 in this study could be related to high sensitivity of the strain and high temperatures experienced in this tropical climate. Apart from that, degeneration of this strain could also be due to genetic alteration and changes in environmental condition.

During soil-casing cultivation, the soil was sterilised before it was used for the casing layer. Cho et al. (2008) reported that compared to sterilised casing layer, nonsterilised casing layer contains more microorganisms which help to promote the formation of fruiting bodies. However, in Malaysia, the tropical climate with high humidity favours the growth of contaminants such as Trichoderma sp. Thus, non-sterilised casing layer may be a suitable habitat for unwanted microorganisms. This should be taken into considerations for the study of cultivation method using soil-casing layer. The $\mathrm{pH}$ value of the soil used in this study was $\mathrm{pH}$ 5. Mycelium started to colonise the soil layer 2 days after the substrate was 
cased, this is in accordance with Klomklung et al. (2014) and Kumla et al. (2013) that mycelial colonisation of $P$. giganteus was optimal at $\mathrm{pH} 5$.

Soil layer functioned as a medium for humidity retention. The cultivation method using soil-casing showed that the soil layer promoted the growth of primordium in the substrate in a shorter period, in agreement with previous reports which indicated that soil-casing helped in improving the growth of Pleurotus mushrooms and promoting primordial production of mushroom (Cho et al. 2008; Kumla et al. 2013). In China and Thailand, $P$. giganteus is cultivated using soil-casing method, which is said to be important for the fruiting stage to promote better yield (Klomklung et al. 2012).

This study was similar to the previous study by Kumla et al. (2013) who reported the pinhead formation after 2 weeks of incubation using soil-casing cultivation method. However, in this study, the cultivated $P$. giganteus parents and hybrids only took 3 to 5 days for the pinhead to develop into matured fruiting body. This result was contrast with the study by Kumla et al. (2013) who reported that the maturation of fruiting bodies of $P$. giganteus took 10 to 15 days.

Biological efficiency is an indication of the yield potential of a strain from a medium. In this study, hybrid IH 32 showed the highest biological efficiency among the cultivated strains. Hence, this hybrid had the highest capability to utilise the saw dust based medium compared to the other cultivated strains. The mean value of the biological efficiency of the hybrids in this study was 34.4 was $48.07 \%$, which was considered slightly low if compared to the previous studies of $P$. ostreatus hybrid with biological efficiency 34.1 to $54.1 \%$ (Kumara \& Edirimanna 2009). Cultivation is the most important stage to evaluate if the breeding study had produced improved strains that gave better yield and morphological characteristics such as larger pilei and better taste (Avin et al. 2016). Formation of fruiting body confirmed that there was a cross of the monokaryons isolated from both parents. In this study, an improved hybrid IH 32 had been produced as it showed higher biological efficiency, number of fruiting body and total number of flushes, as well as shorter period for spawn completion and pinhead formation in comparison to both parents. Cultivation of $P$. giganteus was carried out in small scale in this study. Thus, optimisation of the cultivation method of this species should be conducted on a large scale under farm conditions prior for commercialisation in Malaysia.

Morphological traits on vegetative and reproductive stages might not be sufficient as newly generated hybrids may have similar morphologies and difficult to be discriminated due to lack of clearly distinguishable characters. Molecular identification of newly generated hybrid is important in the mushroom breeding programme (Avin et al. 2016). Integration of morphological and molecular traits have been applied in the development of hybrid strain in edible mushroom (Avin et al. 2016;
Mallick et al. 2017). The ISSR analysis was carried out to assess genetic variations and differentiate hybrids and parents. However, hybrid IH15 shared most of the bands with the maternal strain, KLU-M1391, which could imply that most of the genetic materials from the hybrid might originate from single maternal strain (Guan et al. 2008). Furthermore, recombination might have occurred in the hybrid genome of $\mathrm{IH} 17$ and IH32 as both of the hybrids contained some of the parental bands which can be confirmed as newly developed hybrid.

\section{CONCLUSION}

This study showed that $P$. giganteus strains from different geographic regions, namely China and Malaysia were compatible and were mated successfully with a frequency of $28.6 \%$. In this study, soil-casing cultivation method successfully solved the long coiling stipe formation problem of $P$. giganteus. This is the first mating study of $P$. giganteus in Malaysia. ISSR markers can help in detection of polymorphism among closely related genotype. In this study, hybrid IH17 and IH32 were shown to contain genetic materials from both parents while IH15 shared all loci with KLU-M1391 that could imply high amount of shared genetic materials.

\section{ACKNOWLEDGEMENTS}

This work was financial supported by University of Malaya (RP028B-15AFR, PPP: PG063-2013B). The authors would like to thank Dr. Phan Chia Wei and Dr. Siti Marjiana Binti Ismail for their valuable comments to improve the quality of the paper.

\section{REFERENCES}

Avin, F.A., Bhassu, S., Rameeh, V., Tan, Y.S. \& Vikineswary, S. 2016. Genetics and hybrid breeding of Pleurotus pulmonarius: Heterosis, heritability and combining ability. Euphytica 209: 85-102.

Abdulgani, R., Lau, C.C., Abdullah, N. \& Vikineswary, S. 2017. Morphological and molecular characterization of Pleurotus pulmonarius hybrids with improved sporophore features and higher biological efficacy. International Journal of Agriculture and Biology 19(4): 707-712.

Bao, D., Kinugasa, S. \& Kitamoto, Y. 2004. The biological species of oyster mushrooms (Pleurotus spp.) from Asia based on mating compatibility tests. Journal of Wood Science 50: $162-168$.

Bi, Z., Zheng, G. \& Li, T. 1993. The Macrofungus Flora of China's Guangdong Province. Hong Kong: The Chinese University Press.

Bianco, C.L., Fernandez, J.A., Migliaro, D., Crino, P. \& EgeaGilabert, C. 2011. Identification of F1 hybrids of artichoke by ISSR markers and morphological analysis. Molecular Breeding 27: 157-170.

Brown, A.J. \& Casselton, L.A. 2001. Mating in mushrooms: Increasing the chances but prolonging the affair. Trends Genetics 17(7): 393-400.

Castellani, A. 1968. Long term maintenance and cultivation of the common pathogenic fungi of man in sterile distilled water. Pontificia Academia Scientiarum 17: 1-8. 
Cho, Y.S., Weon, H.Y. \& John, J.H. 2008. Effect of casing layer on growth promotion of the edible mushroom Pleurotus ostreatus. Mycobiology 36(1): 40-44.

Dong, H.X., Cai, D.H. \& Li, Y. 2010. Research situation and prospect of Panus giganteus. Edible Fungi China 29: 3-6.

Doroteo, L.A., Segura, P.B.Z., Arce, R.V., Fernandez, J.Y., Aguilar, M.E.G., Guadarrama, M. \& del Toro, G.V. 2018. Use of ITS and ISSR markers in the molecular characterisation of Pleurotus djmor hybrid strains. Revistra Iberoamericana de Micologia 35(1): 49-55.

Gharehaghaji, A.N., Goltapeh, E.M. \& Masiha, S. 2007. Hybrid production of oyster mushroom Pleurotus ostreatus (Jacq: Fries) Kummer. Pakistan Journal of Biological Sciences 10(14): 2334-2340.

Giraud, T., Yockteng, R. \& Villavicencio, M.L. 2008. Mating system of the anther smut fungus Microbotryum violaceum: Selfing under heterothallism. Eukaryotic Cell 7(5): 765-775.

Gradzielewska, A., Gruszecka, D., Leśniowska-Nowak, J. \& Paczos-Grzęda, E. 2012. Identification of hybrids between triticale and Aegilops juvenalis (Thell.) Eig and determination of genetic similarity with ISSRs. Genetics and Molecular Research 11(3): 2147-2155.

Guadarrama-Mendoza, P.C., del Toro, G.V., Ramírez-Carrillo, R., Robles-Martínez, F., Yáñez-Fernández, J., Garín-Aguilar, M.E., Hernandez, C.G. \& Bravo-Villa, G. 2014. Morphology and mycelial growth rate of Pleurotus spp. strains from the Mexican mixtec region. Brazilian Journal of Microbiology 45(3): 861-872.

Guan, X.J., Xu, L., Shao, Y.C., Wang, Z.R., Chen, F.S. \& Luo, X.C. 2008. Differentiation of commercial strains of Agaricus species in China with inter-simple sequence repeat marker. World Journal of Microbiology and Biotechnology 24: 1617-1622.

Huang, Q.R., Xin, X.L., Yang, L.H. \& Pan, Y.S. 2005. Study of the submerged culture of Clitocybe maxima mycelia and its effect on isolated skeletal muscular fatigue induced by electric stimulation in toad. Food Science 26: 86-90.

Isikhuemhen, O.S., Moncalvo, J., Nerud, F. \& Vilgalys, R. 2000. Mating compatibility and phylogeography in Pleurotus tuberregium. Mycological Research 104(6): 732-737.

Karunarathna, S.C., Yang, Z.L., Raspé, O., Ko Ko, T.W., Vellinga, E.C., Zhao, R.L., Bahkali, A.H., Chukeatirote, E., Degreef, J., Callac, P. \& Hyde, K.D. 2011. Lentinus giganteus revisited: New collections from Sri Lanka and Thailand. Mycotaxon 118: 57-71.

Kaur, S., Kapoor, S. \& Sodhi, H.S. 2014. Screening and evaluation of Agaricus bisporus (Lange) Sing. strains for temperature variability. International Journal of Current Microbiology and Applied Sciences 3(6): 120-127.

Klomklung, N., Karunarathna, S.C., Hyde, K.D. \& Chukeatirote, E. 2014. Optimal conditions of mycelial growth of three wild edible mushrooms from Northern Thailand. Acta Biologica Szegediensis 58(1): 39-43.

Klomklung, N., Karunarathna, S.C., Chukeatirote, E. \& Hyde, K.D. 2012. Domestication of wild strain of Pleurotus giganteus. Sydowia 64(1): 39-53.

Kornerup, A. \& Wanscher, J.H. 1963. Methuen Handbook of Colour. London: Methuen \& Co Ltd.

Kothe, E. 2001. Mating-type genes for basidiomycete strain improvement in mushroom farming. Applied Microbiology and Biotechnology 56(5-6): 602-612.
Kumara, K.W. \& Edirimanna, I.C.S. 2009. Improvement of strains of two oyster mushroom cultivars using duel culture technique. World Applied Sciences Journal 7(5): 654-660.

Kumla, J., Suwannarach, N., Jaiyasen, A. \& Bussaban, B. 2013. Development of an edible wild strain of Thai oyster mushroom for economic mushroom production. Chiang Mai Journal of Science 40(2): 161-172.

Larsen, M.J., Banik, M.T. \& Burdsall, Jr. H.H. 1992. Clamp connections in North American Armillaria species: Occurrence and potential application for delimiting species. Mycologia 84(2): 214-218.

Lee, C.Y., Park, J.E., Lee, J., Kim, J.K. \& Ro, H.S. 2011 Development of new strains and related SCAR markers for an edible mushroom, Hypsizygus marmoreus. FEMS Microbiology Immunology 327(1): 54-59.

Lee, J., Kang, H.W., Kim, S.W., Lee, C.Y. \& Ro, H.S. 2011. Breeding of new strains of mushroom by basidiospore chemical mutagenesis. Mycobiology 39(4): 272-277.

Mallick, P., Chattaraj, S. \& Sikdar, S.R. 2017. Molecular characterizations of somatic hybrids developed between Pleurotus florida and Lentinus squarrosulus through inter-simple sequence repeats markers and sequencing of ribosomal RNA-ITS gene. 3 Biotechnology 7(5): 298-304.

Mensah, D.L.N. \& Obodai, M. 2014. Morphological characteristics of mycelia .growth of two strains of the indigenous medicinal mushrooms, Lentinus squarrosulus Mont. (Singer) on solid media. African Journal of Agricultural Research 9(23): 1753-1760.

MOA. 2019. National Agro-Food Policy 2011-2020 (Dasar Makananan Negara 2011-2020). Bab 7 Memacu Pertumbuhan Pertanian Bernilai Tinggi. pp. 96-98. https:// moa.gov.my/penerbitan. Accessed on 30 April 2019.

Pegler, D.N. 1983. The genus Lentinus: A world monograph. London: Her Majesty's Stationary Office.

Petersen, R.H. \& Bermudes, D. 1992. Intercontinental compatibility in Panellus stypticus with a note on bioluminescence. Persoonia 14(4): 457-463.

Phan, C.W., Wong, J.K., Tan, E.Y.Y., Tan, Y.S., Sathiya Seelan, J.S., Cheah, S.C. \& Sabaratnam, V. 2019. Giant oyster mushroom, Pleurotus giganteus (Agaricomycetes): Current status of the cultivation methods, chemical composition, biological and health-promoting properties. Food Reviews International 35(4): 324-341.

Phan, C.W., David, P., Tan, Y.S., Naidu, M., Wong, K.H., Kuppusamy, U.R. \& Sabaratnam, V. 2014. Intrastrain comparison of the chemical composition and antioxidant activity of an edible mushroom, Pleurotus giganteus, and its potent neuritogenic properties. The Scientific World Journal 2014(1): 1-10.

Phan, C.W., Lee, G.S., Macreadie, I. \& Malek, S.N.A. 2013. Lipid constituents of the edible mushroom, Pleurotus giganteus demonstrate anti-Candida activity. Natural Product Communications 8(12): 1763-1765.

Phan, C.W., Wong, W.L., David, P., Naidu, M. \& Sabaratnam, V. 2012. Pleurotus giganteus (Berk.) Karunarathna \& K.D. Hyde: Nutritional value and in vitro neurite outgrowth activity in rat pheochromocytoma cells. BMC Complementary and Alternative Medicine 12(1): 102-112.

Reddy, M.P., Sarla, N. \& Siddiq, E. 2002. Inter simple sequence repeat (ISSR) polymorphism and its application in plant breeding. Euphytica 128(1): 9-17. 
Royse, D.J. 2003. Cultivation of Oyster Mushrooms. College of Agricultural Sciences, Agricultural Research and Cooperative Extension. The Pennsylvania State University.

Sahoo, A.K., Mohapatra, K.B., Behera, B.B. \& Jadhao, K. 2014. Phylogenetic analysis of high yielding strain of paddy straw mushroom (Volvariella volvacea) by using ISSR markers. Middle East Journal of Scientific Research 21(8): 1197-1202.

Sobal, M., Martínez-Carrera, D., Morales, P. \& Roussos, S. 2007. Classical characterization of mushroom genetic resources from temperate and tropical regions of Mexico. Micologia Aplicada International 19(1):15-23.

Sonnenberg, A.S.M., Baars, J.J.P., Hendrickx, P.M. \& Kerigan, R.W. 2005. Breeding mushrooms: State of the art. Acta Edulis Fungi 12: 163-173.

Stajić, M., Sikorski, J., Wasser, S.P. \& Nevo, E. 2005. Genetic similarity and taxonomic relationships within the genus Pleurotus (higher Basidiomycetes) determined by RAPD analysis. Mycotaxon 93: 247-255.

Urbanelli, S., Della Rosa, V., Punelli, F., Porretta, D., Reverberi, M., Fabbri, A.A. \& Fanelli, C. 2007. DNA-fingerprinting (AFLP and RFLP) for genotypic identification in species of the Pleurotus eryngii complex. Applied Microbiology and Biotechnology 74(3): 592-600.

van Peer, A.F., Park, S.Y., Shin, P.G., Jang, K.Y., Yoo, Y.B., Park, Y.J., Lee, B.M., Sung, G.H., James, T.Y. \& Kong, W.S. 2011. Comparative genomics of the mating-type loci of the mushroom Flammulina velutipes reveals widespread synteny and recent inversions. PloS ONE 6(7): 1-13.

Varshney, R.K., Chabane, K., Hendre, P.S., Aggarwal, R.K. \& Graner, A. 2007. Comparative assessment of EST-SSR, ESTSNP and AFLP markers for evaluation of genetic diversity and conservation of genetic resources using wild, cultivated and elite barleys. Plant Science 173(6): 638-649.

Wakchaure, G.C. 2011. Production and marketing of mushroom: Global and national scenario. In Mushrooms-Cultivation, Marketing and Consumption, edited by Singh, M., Vijaym, B., Kamal, S. \& Wakchaure, G.C. India: Directorate of Mushroom Research. pp. 15-22.
Wong, W.L., Abdulla, M.A., Chua, K.H., Kuppusamy, U.R., Tan, Y.S. \& Sabaratnam, V. 2012. Hepatoprotective effects of Panus giganteus (Berk.) corner against thioacetamide(TAA-) induced liver injury in rats. Evidence-Based Complementary and Alternative Medicine 2012(170303): 1-10.

Yin, Y., Liu, Y., Li, H., Zhao, S., Wang, S., Liu, Y., Wu, D. \& Xu, F. 2014. Genetic diversity of Pleurotus pulmonarius revealed by RAPD, ISSR, and SRAP fingerprinting. Current Microbiology 68(3): 397-403.

Zhang, Q., Xu, B., Liu, L. Yuan, Q., Dong, H., Cheng, X. \& Lin, D. 2012. Analysis of genetic diversity among Chinese Pleurotus citrinopileatus Singer cultivars using two molecular marker systems (ISSRs and SRAPs) and morphological traits. World Journal of Microbiology and Biotechnology 28(5): 2237-2248.

Ha Kwan Yun, Chua Su Boon, Tan Yee Shin* \& Vikineswary Sabaratnam

Mushroom Research Centre

University of Malaya

50603 Kuala Lumpur, Federal Territory

Malaysia

Ha Kwan Yun, Chua Su Boon, Tan Yee Shin* \& Vikineswary Sabaratnam

Institute of Biological Sciences

Faculty of Science

University of Malaya

50603 Kuala Lumpur, Federal Territory

Malaysia

*Corresponding author; email: tanyeeshin@um.edu.my

Received: 3 April 2019

Accepted: 17 February 2020 